\title{
Review of the Values in Biology Textbooks of Secondary Education*
}

\author{
${\text { Bilge } \text { ACAR }^{* *} \quad \text { Melek YAMAN KASAP }}^{* * *}$
}

\begin{abstract}
In this study, it is aimed to examine the value expressions in secondary school biology textbooks. Accordingly, all texts and visuals in the 9th, 10th, 11th and 12th grade biology textbooks were examined, it was determined which root values were conveyed in these textbooks, and the distribution of values conveyed according to subject, unit and grade level were determined. In this research, four books which are accepted as textbooks since the 2018-2019 academic year have been examined. The data were obtained through document examination and analyzed by content analysis method. According to the results obtained, the values in biology textbooks were found to include philanthropy, responsibility and patriotism respectively. Furthermore, it was observed that biology textbooks of secondary education did not contain all ten root values specified in the curriculum, that conveyed values did not show a proportional distribution as per grades and units, and that contents related to values are generally in the form of indoctrination and advice. Results of the research were discussed in terms of possible causes, and recommendations were presented so that value concepts could find more space in biology and science textbooks.
\end{abstract}

Keywords: Values, Values Education, Biology Lesson, Biology Textbooks.

\footnotetext{
${ }^{*}$ This study is the extended version of the paper presented at the International Congress on Education 2019 held at Sakarya University on 19-22 June 2019.

** Orcid ID: https://orcid.org/0000-0003-1419-8571, Ministry of Education, Turkey, bilgeacar05@yahoo.com

*** Orcid ID: https://orcid.org/0000-0002-0932-0241, Prof. Dr., Hacettepe University, Turkey, myaman@hacettepe.edu.tr 


\section{INTRODUCTION}

In our daily lives, the impact of the values of individuals, various selections, and behaviors is undeniable in decisions taken as individuals or members of society. Values are effective in these processes in direct or indirect ways as guiding principles. In other words, owned values directly affect personality traits and guide behaviors (Collins, Steg \& Koning, 2007). There are a number of cultural, moral and political values in each society, and these values play an important role in shaping individual and social life. There are different definitions in the literature on the concept of value: The Turkish Language Authority defines the concept of value as "abstract measure to determine the importance of something, value for something" (Türk Dil Kurumu, 2018). Rokeach (1973), who conducted a lot of research on values, described the concept of value as a permanent belief. According to Schwartz and Bilsky (1987), values are cognitive reflections in which universal needs are represented. Veugelers and Vedder (2003) describe the concept of value as judgments that something is good or bad. Güngör (1998) has described the concept of value as a belief that something is desirable or undesirable. As can be seen from different definitions, values are abstract elements. They are beliefs about what is right, what is wrong, what is good and bad.

Values education is defined as a lifelong education for the individual to gain values, embrace and transform into behavior by making them part of their character (Yaman, 2012). This education can be considered as a process of gaining and socializing one's identity (Kupchenko \& Parsons, 1987). Values education serves young people to create their own values (Kirschenbaum, 1995). Although the acquisition of values begins in the family environment at a young age, educational environments also contribute significantly to the formation process of values through teachers, administrators, peer groups and curriculum. Reasons such as being subjective, varied according to people, society and cultures, and not based on scientifically proven knowledge have made it controversial from time to time that the concept of value should be taught through teaching programs in schools. Today, the dominant view is that education given in schools does not lack values, and that educational environments are aimed at promoting and adopting personal and social values (Lovat \& Toomey, 2009; Mızıkacı, 2015; Zengin, 2017). To raise individuals with national and universal values is accepted among the duties of the school as well as families. Therefore, it is important that the values are given in a planned manner in the education process. Transfer of cultural heritage, social development, and socializing of individuals are carried out with values education. Values education can enable students to teach values outside popular culture, make decisions in accordance with them and determine their behavior (Tezgel, 2006). Gauld and Gauld (2002) indicate that there are two types of cultures: success and character in society and schools. Schools aim not only to educate academically successful individuals, but also to educate people with values and therefore a society with values.

In addition to learning about the cognitive domain, the equipping of students with basic values and skills is among the goals of education in schools. In other words, it is aimed not only to educate individuals equipped with cognitive knowledge and skills in schools, but 
also to educate individuals who are aware of universal values and the national, spiritual and cultural values of the society in which they live, who adopt and respect them. To this end, in recent years, values education in many countries such as New Zealand, America, Australia, Germany and India has become an important educational agenda. The educational process, which plays an important role in shaping the life views of students, is the acquisition and assimilation of scientific attitudes as well as scientific thinking skills; open-mindedness, philanthropy, respect, diligentness, altruism, patience, reconciliation, responsibility, determination, sensitivity to the environment and people, honesty, perseverance, such as many values and personal competence satisfies the acquisition. Since it is considered that schools should take more responsibility for values education, curricula are revised to cover values education and values are included within the scope of various courses. In our country, it is seen that values education is much more prominent in the teaching programs that were renewed in 2005 and even prepared in 2017 and 2018. In the 2017 and 2018 curricula, values were determined in accordance with the general objectives of Turkish National Education and answers questions such as why values are important in teaching programs and how value teaching should be. For example, the 2018 Biology curriculum contains the following explanations about the values (Milli Eğitim Bakanlığı, 2018):

"Our values have reached today and are our own heritage that we will pass on to our future by distilling from the national and spiritual sources of our society. It is an indisputable fact that the future of a society depends on the people who have embraced their values and have these values and who are flesh-and-blooded with the competencies they have. Therefore, our education system acts to give each member the right to make appropriate moral decisions and to demonstrate them in their behavior. The education system is not just a structure that gains some academically successful, determined knowledge, skills and behaviors. It is essential to educate individuals who have adopted basic values; educational system should be able to influence the values, habits and behaviors of the new generation. The education system performs its function in the framework of the goal of bringing values with the training program, which includes training programs. "With this understanding, our values have not been a separate program or learning area, unit, subject, etc. in teaching programs." On the contrary, our values, which are the ultimate purpose and spirit of the entire education process, have been included in each and every unit of the teaching programs" (p.5-6).

As can be seen from the explanations quoted from the Biology curriculum above, values education has been included in the teaching programs prepared at all classroom levels in our country in recent years without discrimination of courses and what the values should be given to the students has been defined in the curriculum. Accordingly, "core values" in the curriculum include justice, friendship, honesty, self-control, patience, respect, love, responsibility, patriotism and charity. To teach core values to students, course content and in-class/off-class applications are expected to be associated with these values. Of course, the values should be taken into consideration and integrated into the contents of course books which are an important complementary material of educational process. 
When the field literature was scanned, it was found that studies on the values transmitted in textbooks were mainly in Turkish (e.g., Gül, 2017; İdi Tulumcu \& Tulumcu 2015; Yaman, Taflan \& Colak, 2009; Yıllar, 2016) and studies conducted in the field of social sciences (e.g., Ersoy \& Şahin, 2012; Kuş, Merey \& Karatekin, 2013) and in the field of science (e.g., Laçin Şimsek, 2004) are limited in number, that there is much less work at the secondary level than the primary education level. Therefore, the subject of this research is an analysis of the value concepts in biology textbooks to contribute to the elimination of this deficiency at both the science and secondary levels. In the study, based on core values specified in secondary biology curriculum, values transferred in biology course book contents were analyzed. To this end, all texts and visuals in the 9th, 10th, 11th and 12th grade biology course books were examined, it was determined which core values were transferred in these course books, and the distribution of values transferred according to subject, unit and grade level were determined in this study.

\section{METHOD}

The study universe consists all biology textbooks, which were taught in secondary education in Turkey in the 2018-2019 academic year and accepted by the Ministry of National Education, and the sample consists of four biology textbooks that are taught in the 9th, 10th, 11th and 12th grades, and that were accepted as textbook for a period of five years as per the decree no. 78 and dated 5/28/2018 by the Head Council of Education and Morality, the Ministry of National Education (Acarlı \& Acarlı, 2018; Bikriç, 2018; Kurt, Çukurova, Kurt, Dikkaya \& Altınpınar, 2018; Suna, 2018). The data of the study was obtained through document review and analyzed by the content analysis method (Mayring, 2000). In the process of obtaining the data, the written texts and images in the four books that constituted the sample were examined and content associated with the 10 core values defined in the curriculum were identified. These sections were selected from textbooks and transferred to the qualitative analysis program as data material. Each core value was treated as a category during the analysis, and the category definitions were created by blending the teaching programs of 2017 prepared by Turkish Language Institution (Türk Dil Kurumu, 2018) and the Ministry of National Education (Milli Eğitim Bakanlığl, 2017). Categories and definitions are as follows:

Justice: To be fair, behave equally, share

Friendship: Altruism, trust, to be loyal, faithful, and solidarity

Honesty: To be clear and understandable, truthful, to behave ethically, to be credible, and to keep your promise

Self-control: To control behaviors, to take responsibility for their behavior, to have selfconfidence

Patience: To be tenacious, not to tolerate 
Respect: To be humble, to treat others the way they want to be treated, to value other people's personalities

Love: To pay attention to family unity, to make sacrifices

Responsibility: To be responsible for yourself, your environment, your country, your family.

Patriotism: To be generous, altruistic, collaborating, compassionate, hospitable, to share Helpfulness: To be generous, altruistic, collaborating, compassionate, hospitable, to share The data was analyzed by MaxQDA 11 program. While coding, value concepts and the above-mentioned definitions of these concepts are used as basis. If the idea to describe in the texts is transferred in a sentence, that single sentence is coded; if the idea is transferred in multiple sentences, all sentences covering the idea are encoded together (once). If the content covers more than one category, it is encoded once for each category in which the same sentence or sentence group can be included. The coding process was conducted independently by two separate researchers specializing in biology education, and the harmony between the codes was examined using Miles and Huberman's formula (Miles and Huberman, 1994). Goodness of fit coefficient between the two researchers was calculated as $92 \%$. To compare the values transferred in textbooks at the class, unit and subject level, the frequencies of the codes obtained as a result of content analysis are presented in the form of tables. To compare the values transferred in textbooks at the class, unit and subject level, the frequencies of the codes obtained as a result of content analysis are presented in the form of tables.

\section{FINDINGS}

Frequency and percentages of the value expressions identified as a result of the examination based on the core values determined in the curriculum in secondary school 9th, 10th, 11th and 12th-grade biology textbooks were given in Table 1.

Table 1

9, 10, 11 and 12. Frequency and Percentages of Value Expressions Transmitted in Class Biology Textbooks

\begin{tabular}{lcc}
\hline Code name & Frequency & $\%$ \\
\hline Helpfulness & 30 & 33 \\
Responsibility & 25 & 27.5 \\
Patriotic & 15 & 16.5 \\
Self inspection & 10 & 11
\end{tabular}




\begin{tabular}{lcc} 
Respect & 5 & 5.5 \\
Patience & 2 & 2.2 \\
Love & 2 & 2.2 \\
Friendship & 2 & 2.2 \\
Honesty & - & - \\
Law & - & - \\
Total & 91 & 100 \\
\hline
\end{tabular}

A total of 91 value expressions were detected in the 9th, 10th, 11th and 12th-grade biology textbooks. The texts quoted in biology textbooks contained mostly values such as "philanthropy, responsibility, patriotism and self-control". While there were very few places to value "love, respect, friendship and patience", values such as "justice and honesty" were never included. The textbooks examined are expected to include all 10 core values set in the curriculum, while 2 core values (justice and honesty) are not included in any books.

When the distribution of value expressions transmitted in textbooks as per grade were examined (Table 2), value statements specified in the classroom biology textbook, which were expected to be transmitted in textbooks, were not found in the 9th grade biology textbooks.

Table 2

Distribution of value expressions given in 9th, 10th, 11th and 12th grade biology textbooks as per grades

\begin{tabular}{|c|c|c|c|c|c|c|c|c|}
\hline \multirow{2}{*}{ Code name } & \multicolumn{2}{|c|}{ 9th grade } & \multicolumn{2}{|c|}{10 th grade } & \multicolumn{2}{|c|}{ 11th grade } & \multicolumn{2}{|c|}{12 th grade } \\
\hline & $f$ & $\%$ & $\mathrm{f}$ & $\%$ & $\mathrm{~F}$ & $\%$ & $\mathrm{f}$ & $\%$ \\
\hline Law & - & - & - & - & - & - & - & - \\
\hline Friendship & - & - & - & - & 1 & 9.1 & 1 & 2.2 \\
\hline Honesty & - & - & - & - & - & - & - & - \\
\hline $\begin{array}{l}\text { Self } \\
\text { inspection }\end{array}$ & - & - & 8 & 23.5 & - & - & 2 & 4.3 \\
\hline Patience & - & - & - & - & - & - & 2 & 4.3 \\
\hline Respect & - & - & 1 & 2.9 & 2 & 18.2 & 2 & 4.3 \\
\hline Sakary & ity & of Ed & & & & & & \\
\hline
\end{tabular}




\begin{tabular}{lcccccccc} 
Love & - & - & 1 & 2.9 & 1 & 9.1 & - & - \\
Responsibility & - & - & 19 & 55.9 & 1 & 9.1 & 5 & 10.9 \\
Patriotic & - & - & 5 & 14.7 & 1 & 9.1 & 9 & 19.6 \\
Helpfulness & - & - & - & - & 5 & 45.5 & 25 & 54.3 \\
Total & - & - & 34 & 100 & 11 & 100 & 46 & 100 \\
\hline
\end{tabular}

34 value expressions identified in the 10th grade Biology textbook covered contents associated with the categories such as "responsibility, self-control, patriotism, respect and love". While the 10th grade textbook contained mostly the value expressions for responsibility, value expressions regarding justice, friendship, honesty, patience and charity were not identified. In the 10th grade biology textbook, the distribution of contents associated with core values were also not proportionate. While all the values contained in the book were included in the "Ecosystem Ecology and Current Environmental Issues" unit, no value expressions were included "Cell Divisions" and "General Principles of Inheritance" units. In addition, value expressions were transferred directly and sometimes indirectly in texts. In Table 3, examples are presented related to contents in which the values were transferred in the 10th grade biology textbook.

Table 3

Content Samples in the 10th Grade Biology Textbook where core Values were Transferred

\begin{tabular}{|c|c|}
\hline Category & Sample expression \\
\hline Self-control & $\begin{array}{l}\text { Protecting and not polluting the } \\
\text { environment is the duty of the state as } \\
\text { well as individuals. } \\
\text { In the household appliances we use, } \\
\text { household appliances that are saving } \\
\text { for water consumption should be } \\
\text { preferred. Wastewater should be } \\
\text { treated by refining. }\end{array}$ \\
\hline Love & $\begin{array}{l}\text { Human beings should love the } \\
\text { creatures and natural life they live } \\
\text { together in nature. }\end{array}$ \\
\hline
\end{tabular}

Responsibility

It is our duty to protect forests. 


\begin{tabular}{ll}
\hline & $\begin{array}{l}\text { Protecting the biosphere, a balanced } \\
\text { ecosystem, is one of the main tasks of } \\
\text { all mankind. }\end{array}$ \\
Patriotic & $\begin{array}{l}\text { Therefore, it is the duty of all of us to } \\
\text { protect our country, which has such } \\
\text { important areas ecologically. }\end{array}$
\end{tabular}

A total of 11 value expressions were detected in the 11th-grade biology textbooks (Table 4). The most frequently transferred value in the 11th grade is "Philanthropy". While the expressions in which "friendship, respect, love, responsibility, patriotism" values were conveyed were very small in numbers, no expressions were determined in which the values of "justice, honesty, self-control and patience" were conveyed. All the values contained in the book were included in the "Human Physiology" unit, and the values transferred were usually given through similar themes. Some of the values were directly given indirectly, while others were indirectly given and often referred to as advice and suggestions. Almost no place was given the activities where students actively participate in the learning process. Table 4 contains examples of categories identified in the textbook and the contents in which these categories are transferred.

Table 4

Content Samples in the 11th Grade Biology Textbook where core Values were Transferred

\begin{tabular}{ll}
\hline Category & Sample expression \\
\hline Love & $\begin{array}{l}\text { Sibling bond is usually the longest-term relationship in our lives, } \\
\text { providing a suitable environment for sharing feelings of love, respect } \\
\text { and trust. }\end{array}$ \\
Responsibility & $\begin{array}{l}\text { It should be known that the two kidneys, liver, lungs, intestines, } \\
\text { corneas and even bones of the deceased will save many people's }\end{array}$ \\
& lives. If no donations are made, the organs will rot under the ground. \\
Patriotic & "Annual Yasargil" conferences were launched at the Swiss Medical \\
& Faculty in November 2014, honoring Yasargil's work and \\
& contributions at the University of Zurich. \\
Helpfulness & You can donate blood at the Turkish Red Crescent Blood Donation \\
& Centers.
\end{tabular}

A total of 46 value expressions are included in the 12th-grade biology textbooks. In the 12th grade biology textbook, it was determined that the values of "philanthropy, patriotism and responsibility" were transferred. "Self-control, friendship, respect, 
patience" were included for a few times, and "justice honesty and love" values were never included. Seven out of 10 core values were identified in the 12 th grade textbook. Distribution of transferred values by unit and subjects is not homogeneous. For example, 25 statements about philanthropy, 9 expressions related to patriotism, 5 expressions related to responsibility were identified, other core values were either never included or very few were included. As in other grades, in the 12 th-grade textbook, some of the values were directly quoted, while others were quoted in indirect statements. Table 5 contains categories identified in the textbook and content samples in which these categories are transferred. As can be seen from the examples, contents covering values in this class are usually in the form of recommendation and indoctrination.

\section{Table 5}

Content Samples in the 11th Grade Biology Textbook where Core Values were Transferred

\begin{tabular}{ll}
\hline Category & Sample expression \\
\hline Friendship & These dishes are often shared with the neighbors. \\
Self-control & To prevent global warming, we should be environmentally \\
& sensitive, responsible, do not waste natural resources and consume \\
& consciously, protecting their natural habitats. \\
& To combat obesity, individuals need to control their eating behavior \\
& and take responsibility for their behavior. \\
& Individuals treated for obesity should complete the treatment \\
& process in a determined manner by receiving support from family \\
& members and friends in the process of returning to their ideal \\
& weight. \\
& Aziz Sancar, who carried on values such as patience, determination, \\
& perseverance, being a good observer and working hard, was the \\
& architect of a success that started in Mardin to receive the Nobel \\
& Prize. \\
& To prevent global warming, we should be environmentally \\
sensitive, responsible, do not waste natural resources and consume \\
consciously, protecting their natural habitats. \\
Therefore, the winner of this award delivered his Nobel prize, \\
medal and the certificate to the Anitkabir saying "Owner of this \\
award is Atatürk and the Museum representing the Republic of \\
Turkey". \\
Share tasks and work with your group friends by choosing among \\
them.
\end{tabular}




\section{CONCLUSIONS, DISCUSSION AND RECOMMENDATIONS}

The values that children and young people care about and adopt are effective in their behavior and decisions at every stage of their lives. Although the view that educational institutions remain neutral on subjective subjects such as values education is sometimes dominated (Loeser, 2008), the developments in science and technology and the effects of globalization and the change in social and cultural life are very fast, today, the transfer of values in schools through teaching programs is an important educational agenda in many countries. In our country, especially since 2005 , some courses, especially social studies courses, have been included in values education in the teaching programs and the importance of values education has been emphasized in the circulars issued by the Ministry of National Education (Talim ve Terbiye Kurulu Başkanlığı, 2010). Values education has also been prominent and detailed in the biology curriculum, which was prepared in 2017 and revised in 2018. Since textbooks remain an important course material in obtaining the content and gains determined by the curriculum, biology textbooks are examined in this study in terms of the values passed on, and the results are discussed below.

According to the research results, it was found that the values transferred in the 9 th, 10th, 11th and 12th-grade biology textbooks did not show a proportional distribution according to grades and units. For example, while expressions conveying the 10 core values were not determined in curriculum of the 9th class biology textbook, it was observed that only some of the core values were conveyed in the 10th, 11th, and 12thgrade textbooks, and their distribution at the subject and unit level was not proportionate. Course books are expected to overlap with the curriculum at the maximum level in terms of content and learning outcomes. Therefore, not only cognitive gains but also the philosophy of the curriculum should be considered in the textbook writing process. One of the most important issues in the 2018 Biology curriculum is values education. However, the research results showed that 10 core values in the curriculum were not adequately conveyed in the course books and were not sufficiently compatible with the curriculum.

When the texts in 10th, 11th and 12th textbooks were analyzed, it was observed that they were usually in the form of suggestion or advice and were interspersed with the information that conveyed the field content. No activities, discussions, applications, etc. were detected regarding understanding and gaining values. Values in schools are aimed at giving students suitable opportunities to internalize values in school and non-school environments and contribute to them converting them into practice (Milli Eğitim Bakanlığl, 2017). Texts in textbooks where value transfers are detected are far from giving students the expected contribution to their own values and to gain skills such as research, discussion, questioning, associating in their current form. Values education is being developed in a way that enables critical thinking in the student rather than the imposition of values (Lickona, 1991). Students are not passive recipients in the value gain process as well as in the acquisition of academic knowledge and skills (Ryan \& Bohlin, 1999; Thornberg, 2006). For this reason, textbooks encourage students to actively discuss, 
experience and adopt such values by discussing, and include guiding activities and content.

The 10 core values in the teaching programs are common for all courses (Milli Eğitim Bakanlığl, 2017). Undoubtedly, in the process of determining these values, social expectations, the expectations of families are considered, and a detailed analysis of the qualifications expected from each member of society now and in the future is carried out. As in other courses, the core values in the biology curriculum have been included in a general framework as a personality trait such as respect, love, responsibility, justice. However, basic values such as love, respect, responsibility, justice are the basic values that should be mainly gained in the family, preschool and primary education process. It is thought that the fact that not all the core values were given in the biology textbooks examined in the research may result from that these values were discussed in an overall context in the curriculum, and that they were not adapted to the biology and science contents. It is recommended to provide a customized values education according to the content of the courses by taking advantage of these basic values that have been gained in previous educational levels at the secondary level.

As in other science field courses, research, sample courses, activities and course materials for biology courses within the scope of values education are almost nonexistent. Studies in science are mainly within the framework of environmental ethics, environmental education and aesthetic values. However, science field contents have a very strong relationship with values. The values adopted by the students will create a guiding force in their decisions, attitudes and behaviors in subjects related to nature and living things, such as nature and living things, health, as in all areas of life (Braus \& Wood, 1993). Values integrated with science and technology courses have an impact on students gaining a variety of universal values (Kunduroğlu, 2010). Therefore, it is recommended that values education be integrated into field-specific content in various courses instead of being given in a standard framework for each course and to treat them with contexts, methods and activities suitable for the field. For example, it is recommended that the values appropriate to the characteristics of the content, such as the protection of biodiversity in the acquisition of values such as "respect" and "responsibility" within the scope of biology course, and the acquisition of responsible consumption behavior for the protection of natural resources in order to achieve sustainable development goals, are transferred with various contexts, methods and practices.

It is thought that the lack of all values in biology textbooks, the lack of homogeneous distribution, the fact that the content is included in the form of suggestions and recommendations may be due to a lack of knowledge, experience and material in the form of integrating values into science content. In this regard, there is a need to quickly develop and promote rare materials and examples of courses for secondary school science courses. The development of exemplary applications, materials and activities that can be used in the fields of values education approaches, biology and other science, and the introduction of them on various platforms will provide an important guidance and 
support to teachers and anyone who has a role in the values education process, especially the textbook authors.

As practitioners of curriculum gains and textbook content in the classroom environment, the readiness of teachers in these subjects is an important factor in order for values to be carried out in an integrity of education. When the teaching programs of the faculty of education are examined as teachers, it is seen that values education is included within the scope of the New Teacher Training Undergraduate Programs prepared by the Higher Education Board. For example, ethics and ethics in Education, "Character and Value Education" courses were included in biology physics and chemistry teacher training programs, and values and values education in the content of some other courses were included as sub-headings (Yükseköğretim Kurulu, 2018a; Yükseköğretim Kurulu, 2018b; Yükseköğretim Kurulu, 2018c). However, it is noted that the lessons and contents related to values education are discussed in a general context and are specific to disciplines and are not customized. This raises the problem of future teachers graduating in the education process without having enough knowledge and experience to integrate values into their own areas of course content (Yazıcl, 2006). To carry out an effective values education in science field courses in the future, it is recommended that the course content for values education be expanded to include field-specific topics in teacher training programs.

\section{References}

Acarlı, D., \& Acarlı, H. (2018). Ortaöğretim Biyoloji 11 Ders Kitabı [Secondary Education Biology 11 Textbook]. Ankara: Kök Yayınları.

Bikriç, S. (2018). Ortaöğretim Biyoloji 10 Ders Kitabı [Secondary Education Biology 10 Textbook]. Ankara: Berkay Yayınları.

Braus, J. A., \& Wood, D. (1993). Environmental education in the schools: Creating a Program that Works. Washington: D.C.: Peace Corps Information Collection and Exchange.

Collins, C. M., Steg, L., \& Koning, M. A. S. (2007). Customers' values, beliefs on sustainable corporate performance, and buying behavior. Psychology \& Marketing, 24(6), 555-577.

Ersoy, F., \& Şahin, T. (2012). Sosyal Bilgiler Ders Kitaplarının Değerler Eğitimi Yaklaşımları Açısından İncelenmesi [Examination of Social Studies Textbooks in terms of Approaches of Values Education]. Kuram ve Uygulamada Eğitim Bilimleri, 12(2), 1535-1558.

Gauld, L., \& Gauld, M. (2002). The biggest job we'll ever have: The hyde school program for characterbased education and parentin. New York: Library of Congress Cataloging in Publication Data.

Gül, M. (2017). Türkçe Ders Kitabındaki Metinlerin (5. Sınıf) Değerler Eğitimi Yaklaşımıyla İncelenmesi [An Investigation of Values in Turkish Textbook (5th Grade) a Valuable Education Approach]. Erciyes Ĕgitim Dergisi, 1(1), 59-78.

Güngör, E. (1998). Ahlak psikolojisi ve sosyal ahlak [Moral Psychology and Social Morality]. İstanbul: Ötüken Yayınevi. 
İdi Tulumcu, F., \& Tulumcu, F. M. (2015). İlköğretim İkinci Kademe Türkçe Dersi Programlarında Yer Alan Değerler [Values Involved in Turkish Lesson Curriculum in Second Stage of Elementary Education]. Değerler Eğitimi Dergisi, 13(29), 535-560.

Kirschenbaum, H. (1995). Enhance Values and Morality. Boston: Allyn and Bacon.

Kunduroğlu, T. (2010). 4. Sinıf Fen ve Teknoloji Öğretim Programıyla Bütünleștirilmiş Değerler Eğitimi Programının Etkililiği [The Effectiveness of 'Values Education' Program Integrated With the 4th Grade Science and Technology Instructional Program] (Master Thesis). Ankara Üniversitesi, Ankara.

Kupchenko, I., \& Parsons, J. (1987). Ways of Teaching Values: An Outline of Six Values Approaches. Retrieved from https://files.eric.ed.gov/fulltext/ED288806.pdf

Kurt, F., Çukurova, F., Kurt, H. B., Dikkaya, S., \& Altınpınar, S. (2018). Ortaöğretim Biyoloji 12 Ders Kitabı [Secondary Education Biology 12 Textbook]. Ankara: MEB Yayınları.

Kuş, Z., Merey, Z., \& Karatekin, K. (2013). İlköğretim 4. ve 5. Sınıf Sosyal Bilgiler Ders Kitaplarında Yer Alan Değerler [Values in Primary Education 4th and 5th Grade Social Studies Textbooks]. Değerler Eğitimi Dergisi, 11(25), 183-214.

Laçin, Şimşek, C. (2004). Fen Bilgisi Öğretim Programı ve Ders Kitaplarına Göre Çevre Eğitiminde Etik ve Estetik Değerler [Ethical and Aesthetic Values in Enviromentel Education in Science Education Curriculum and Textbooks]. Değerler Eğitimi Dergisi, 2(7-8), 127-146.

Lickona, (1991). Educating for character. New York: Bantam Books.

Loeser, J. (2008). Values, Character, and Moral Education. Research Starters Education. Retrieved from http://eds.b.ebscohost.com/eds/detail

Lovat, T., \& Toomey, R. (2009). Values Education and Quality Teaching: The Double Helix Effect. Sydney: Springer Science Business Media B. V.

Mayring, P. (2000). Qualitative Inhaltsanalyse. Grundlagen und Techniken. Weinheim: Deutscher Studien Verlag.

Mızıkacı, F. (2015). Değerler Eğitimi ve Eğitim Programları [Values Education and Curriculum]. Eleştirel Pedagoji Dergisi 40, 3-7.

Miles, M. B., \& Huberman, A. M. (1994). Qualitative data analysis: An expanded sourcebook. Beverly Hills: Sage publications.

Milli Eğitim Bakanlığı [Ministry of Education]. (2017). Biyoloji 9-12. Sinıflar biyoloji dersi öğretim programı [High school Biology 9-12 Curriculum]. Ankara.

Milli Eğitim Bakanlığı [Ministry of Education]. (2018). Biyoloji 9-12. Sinıflar biyoloji dersi öğretim program [High school Biology 9-12 Curriculum]. Ankara.

Rokeach, M. (1973). The Nature of Human Values. New York: The Free Press.

Ryan, K., \& Bohlin, K. (1999). Building Character in Schools. California: Jossey-Bass.

Schwartz, S. H., \& Bilsky, W. (1987). Toward a universal psychological structure of human values. Journal of Personality and Social Psychology, 53, 550- 562.

Suna, Ö. (2018). Ortaöğretim Biyoloji 9 Ders Kitabı [Secondary Education Biology 9 Textbook]. İstanbul: Netbil Yayınları.

Talim ve Terbiye Kurulu Başkanlığı [Board of Education and Morality. (2010). Illk ders genelgesi [First lecture Cirrucular]. B.08.0.TTK.0.72.02.00, 08.09.2010. 
Türk Dil Kurumu [Turkish Language Institution]. (2018). Büyük Türkçe Sözlük [Great Turkish Dictionary]. Retrieved from http://tdkterim.gov.tr/bts/

Tezgel, R. (2006). Yeni ilköğretim sosyal bilgiler dersi öğretim programında insan hakları ve değer eğitimi [Human rights and value education in the new primary education social studies curriculum]. II. Uygulamalı Etik Kongresi Bildiri Kitabı, 637-645. Ankara: ODTÜ Yayınları.

Thornberg, R. (2006). Hushing as a moral dilemma in the classroom. Journal of Moral Education, 35(1), 89-104.

Veugelers, W., \& Vedder, P. (2003). Values in teaching. Teachers and Teaching: Theory and Practice, 9, 377-389.

Yaman, H., Taflak, S., \& Çolak, S. (2009). İlköğretim ikinci kademe Türkçe ders kitaplarında yer alan değerler [Values Involved in Turkish Lesson Curriculum in Second Stage of Elementary Education]. Değerler Eğitimi Dergisi, 7(18), 197-120.

Yazıcı, K. (2006). Değerler Eğitimine Genel Bir Bakış [General View to the Values Education]. Türklük Bilimi Araştırmaları, 19, 499-522.

Yıllar, R. (2016). İlettiği Değerler Açısından İlkokul Türkçe Ders Kitaplarındaki Metinler Üzerinde İncelemeler [Reviews on Turkish Elementary School Textbooks interms of the Value Message]. Bayburt Eğitim Fakültesi Dergisi, 1(2), 490-506.

Yükseköğretim Kurulu [Higher Education Council] (2018a). Biyoloji Öğretmenliği Lisans Programı [Biology Teaching Undergraduate Program]. Retrieved from https://www.yok.gov.tr/Documents/Kurumsal/egitim ogretim dairesi/Yeni-OgretmenYetistirme-Lisans-Programlari/Biyoloji Ogretmenligi Lisans Programi.pdf

Yükseköğretim Kurulu [Higher Education Council] (2018b). Fizik Öğretmenliği Lisans Programı [Physics Teaching Undergraduate Program]. Retrieved from https://www.yok.gov.tr/Documents/Kurumsal/egitim ogretim dairesi/Yeni-OgretmenYetistirme-Lisans-Programlari/Fizik Ogretmenligi Lisans Programi.pdf

Yükseköğretim Kurulu [Higher Education Council] (2018c). Kimya Öğretmenliği Lisans Programı [Chemistry Teaching Undergraduate Program]. Retrieved from https://www.yok.gov.tr/Documents/Kurumsal/egitim ogretim dairesi/Yeni-OgretmenYetistirme-Lisans-Programlari/Kimya Ogretmenligi Lisans Programi.pdf

Zengin, M. (2017). Bir Uygulama Modeli Olarak Avustralya'daki Okullarda Değerler Eğitimi [Values Education in Australian Schools as a Model Case]. Uluslararası Sosyal Araştırmalar Dergisi, 10 (52), 866-883. 